\title{
1998 ice storm impact on sugar bushes of eastern Ontario
}

\author{
by Thomas L. Noland ${ }^{1}$
}

In 1998, thirty-four managed sugar bush blocks with $7 \%$ to $72 \%$ ice-induced crown damage were established in eastern Ontario. All received dolomitic lime $(\mathrm{Ca}, \mathrm{Mg})$ and $\mathrm{P}$ and $\mathrm{K}$ treatments in June 1999. Initial crown damage, fall root starch and sugar levels, sap production and sweetness, sap amino acid concentration, and tap hole closure rate were measured. Syrup production was calculated. Trees with $>50 \%$ (severe) crown damage had reduced root starch content in 1998 and 2000, but not in 1999. In 2000, root total sugars were lower in trees with $>50 \%$ crown damage. Sap produced per tap, and sap sweetness were reduced by damage, but not consistently in all years. Sap per tap increased with total crown branches in all three years, but sap sweetness and syrup production only in 1999. Syrup production per tap was consistently reduced in damaged trees in all three years, usually in trees with $>50 \%$ damage. The lime and $\mathrm{P}$ and $\mathrm{K}$ treatments did not significantly affect any of the variables measured. Results suggest that severe ice storm damage to crowns resulted in reduced fall root starch levels and less sap production, and/or sap sweetness, and therefore lowered the syrup producing capacity of sugar maple.

\section{Keywords: Acer saccharum, ice storm, sap and syrup production, root starch, crown damage}

En 1998, trente quatre blocs d'érablière à sucre aménagée ayant subi entre $7 \%$ et $72 \%$ de dégâts causés par la glace au niveau de la cime, ont été mis en place dans l'est de l'Ontario. Tous ces blocs ont reçu de la chaux dolomitique (Ca, Mg) et des traitements de $\mathrm{P}$ et de $\mathrm{K}$ en juin 1999. Les dégâts initiaux au niveau de la cime, le contenu en amidon des racines à l'automne, la production de sève et son contenu en sucre, la concentration en acides aminés de la sève et le taux de fermeture de l'entaille ont été mesurés. La production de sirop a été calculée. Les arbres ayant plus de $50 \%$ de la cime endommagée avaient un contenu réduit en amidon au niveau des racines en 1998 et en 2000, mais pas en 1999. En 2000, le niveau total de sucre dans les racines était inférieur pour les arbres ayant plus de $50 \%$ de la cime endommagée. La production de sève par entaille et le taux de sucre de la sève ont été réduits par suite des dégâts, mais pas de façon constante pour toutes ces années. La quantité de sève par entaille s'est accrue en fonction du nombre total de branches dans les cimes, mais le taux de sucre et la production de sirop seulement en 1999. La production de sirop par entaille a été réduite de façon constante pour les arbres endommagés au cours des trois années, habituellement pour les arbres ayant plus de $50 \%$ de dégâts. Les traitements de chaux, de $\mathrm{P}$ et de $\mathrm{K}$ n'ont pas eu un effet significatif sur aucune des variables mesurées. Les résultats suggèrent que les dégâts sévères occasionnés par le verglas aux cimes ont entraîné une réduction des niveaux d'amidon dans les racines à l'automne et une production réduite de sève ou encore du taux de sucre dans la sève, et en conséquence une réduction de la capacité de production de sirop chez l'érable à sucre.

Mots-clés: Acer saccharum, tempête de verglas, production de sève et de sirop, amidon des racines, dégât de cime

\section{Introduction}

The ice storm of January 5-10, 1998 was unprecedented in its duration, severity, and area affected (Chapeskie 1999). Perhaps the most unusual part of this weather event was the extended length of time the icing conditions persisted. At its peak, freezing precipitation extended from the Muskoka region in central Ontario to Kitchener in southern Ontario and eastward to the New Brunswick in Canada. In the United States it covered northern sections of New York and the New England states (Van Dyke 1999, Irland 1998). The most severely affected area had ice accumulations of 50 to $100 \mathrm{~mm}$, which were caused by three icing episodes over five days (Proulx and Greene 2001). It was one of the worst weather disasters ever recorded in Canadian history (Milton and Bourque 1999).

The ice storm caused extensive damage to the crowns of most hardwood and many coniferous trees in eastern Ontario, the area most severely affected in Ontario. Sugar maple trees suffered extensive crown damage throughout the region. The number of sugar maple taps in Ontario lost due to ice storm damage has been estimated to be $12.5 \%$ of the provincial total (Irland 1998). Critical research needs identified by maple syrup producers included the impact of crown damage on root starch level,

${ }^{1}$ Ontario Ministry of Natural Resources, Ontario Forest Research Institute, 1235 Queen St. E., Sault Ste. Marie, ON P6A 2E5. E-mail: tom.noland@mnr.gov.on.ca sap production and sweetness, and on the rate of recovery or decline for damaged sugar bushes (Chapeskie and Nielsen 1998).

The effect of ice-storminduced crown damage on sugar maple root starch concentration, sap production and sap sweetness has not been reported (Coons 1999). However, significantly reduced fall root starch (Wargo et al. 1972) and fall root total non-structural

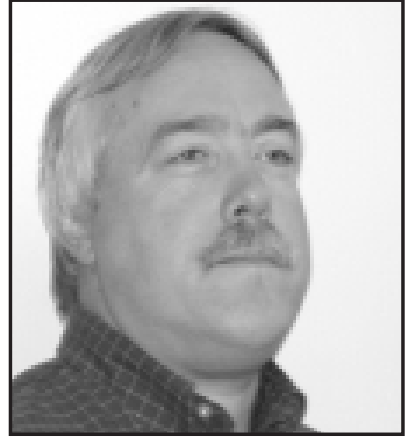

Thomas L. Noland carbohydrate (TNC) levels (Kolb et al. 1992) induced by recent defoliation have been reported for sugar maple. In addition, insect defoliation reduced the amount and sweetness of sap produced the spring after defoliation (Kolb et al. 1992). The most severely defoliated ( $>90 \%$ foliage insect damaged) sugar maple trees, compared to trees with less damage, continued to have lower fall root TNC levels one year after the insect attack (Kolb et al. 1992). In fact, sugar maple roots were more sensitive to stress than other tissues because of their importance as a storage organ for starch, and measures of root carbohydrates were valuable in assessing tree health (Renaud and Mauffette 1991). 
After the 1998 ice storm, the maple syrup producers of Eastern Ontario were concerned about the adverse effect of the ice storm damage on condition and productivity of their sugar maple trees. Therefore, the primary objective of this project was to determine whether ice storm damage to the crowns of sugar maple trees in working sugar bushes affected their health and productivity. This was assessed by measuring the amount of starch stored in the roots, the volume and sweetness of the sap produced, and the rate of tap hole closure. A secondary objective was to determine whether fall root starch content was correlated with the amount and sweetness of sap produced the following spring. A final objective was to determine whether lime and fertilizer treatments could accelerate the recovery process.

\section{Methods \\ Plot Network}

In 1998, 34 1-ha blocks were established throughout the heavily ice-damaged area of eastern Ontario in privately owned sugar bushes (Lautenschlager and Nielsen 1999). Each block was rated for ice damage by visually estimating the percentage of branches in each tree's crown that were removed by ice damage (Lautenschlager and Winters 2001). Each block was divided into four, 0.25 -ha plots that were treated (except the non-tapped block) with either: i) 2 tonnes of dolomitic lime/ha; ii) $200 \mathrm{~kg}$ of P and $\mathrm{K} / \mathrm{ha}$; iii) lime plus $\mathrm{P}$ and $\mathrm{K}$, or iv) nothing (control) in June 1999. At the time of establishment, six focus trees per plot (24 per block) were chosen to represent the average damage in the block and were marked for use in the study. To avoid edge effects, the six trees were chosen to be in the centre of each plot, usually at least $10 \mathrm{~m}$ from the plot edge. The blocks are separated into four physiographic regions, with region 1 being the Canadian Shield, region 2, the limestone plain, region 3, the Ottawa River Valley, and region 4, the St. Lawrence River Valley. At establishment, the following parameters were measured: I) tree damage, II) focus tree diameter at breast height (dbh), III) basal area $\mathrm{m}^{2} \mathrm{ha}^{-1}$, IV) and root diameter of two roots sampled per tree for starch. Soil data (such as soil pH, Ca, K, $\mathrm{Mg}$, and P, plus soil clay, silt, and sand content) were obtained from a companion maple project (Timmer et al. 2003) and total branch counts were conducted as described in Lautenschlager and Winters (2001).

\section{Root Starch and Sap Sampling}

Root starch samples were collected by taking late fall (Nov. or early Dec.) (Wargo 1979) increment cores, 2-3 cm long, from two surface roots $($ mean diameter $=10.5 \mathrm{~cm}$, range $5-18 \mathrm{~cm}$ ) per tree of three focus trees per treatment plot (12 trees per block). All 34 blocks were sampled for root starch in 1998 and 1999. Root starch results for all 34 blocks were statistically compared to results from the 15 sap collection blocks after 1999 and found to be essentially the same $(\mathrm{P} \leq 0.05)$ (data not shown). Therefore, root starch data presented represent the 15 sap collection blocks for all years. However, there were actually 16 sap collection blocks used (Table 1), with Block 2 replacing Block 11 in 2000 and 2001. Total soluble sugars were also analyzed for the fall 2000 root samples.

Trees were tapped using standard $11.1 \mathrm{~mm}$ (7/16") diameter spiles with a tap hole $6.35 \mathrm{~cm}$ (2.5") deep using conservative tapping guidelines: a maximum of two taps per tree (Chapeskie and Nielsen 1998). Sap was collected using a tube and bucket system. The buckets had 19-litre capacity with plastic lids to prevent rain or snow dilution. Sap collection was made from the same three focus trees per plot as root starch. Fifteen blocks had sap collections made in the spring of 1999, 2000 , and 2001. Sap volume production was determined by weighing buckets about every second day during sap runs. Twenty $\mathrm{ml}$ sap samples for sugar content analyses were taken periodically (four to 12 times, except in the short sap run season of 1998 when two blocks had three collections and one block had two collections) through the season, depending on length of sap run. Syrup production was calculated two different ways: 1) total seasonal sap volume and seasonal average sugar concentration, and 2) the periodic sap sugar samples and sap production data corresponding to that period, with both using the rule of 86 (N.B. the appropriate value is now 87) to calculate syrup production (Walters 1982). Statistical analysis of both methods showed slight but usually statistically insignificant differences between the two methods in amounts of syrup production calculated in one year, but no significant differences between the results of the two methods related to damage or any other variables (data not shown). Data presented is from the seasonal average method.

\section{Amino Acid, Sugar, and Starch Analysis}

Amino acids were analyzed from 16 dates of sap samples collected from Block 14 during the 2000 sap season. Block 14 was chosen because of its relatively acid soil $\mathrm{pH}$ of 5.1 . Because of the low soil $\mathrm{pH}$, the lime and fertilizer treatments were thought likely to cause effects. Amino acids were analyzed by taking $20-\mu \mathrm{l}$ samples of sap and derivatizing the amino acids with a fluorescent tag using Waters' Ltd. AccQ-Tag ${ }^{\mathrm{TM}}$ method (Waters Ltd., Mississauga, ON, Canada). The derivatized samples were run on a Waters' HPLC system containing an AccQ-Tag column and using a gradient elution to separate the individual amino acids. A Waters 464 fluorescence detector was used to quantify the amino acids and the data were collected and processed using Waters Millenium chromatography software.

Extraction of total soluble sugars and starch (total nonstructural carbohydrates) used $1.5 \mathrm{ml}$ of methanol: chloroform: water mixture (12:5:3 by volume) (Haissig and Dickson 1979) and was done three times on each $25 \mathrm{mg}$ DM (freeze-dried mass) root tissue sample (ground with size 20 mesh). Root starch and sap sugars were analyzed using a Waters' HPLC system as described in Noland et al. (1997).

\section{Experimental Design and Statistical Approach}

The experiment is a split-plot completely randomized block design. The main effects being investigated are four physiographic regions:

i) Canadian Shield,

ii) Limestone Plain,

iii) Ottawa River Valley, and

iv) St. Lawrence River Valley

and three crown damage levels (within each region):

i) Light (0-25\% damage),

ii) Moderate (26\%-50\%), and

iii) Severe damage $(51 \%+)$.

The split for each 1-ha block is the following treatments: fertilizer, liming, fertilizer + liming, and control applied randomly to one of the four subplots. The initial design called for three blocks (replications) of each damage level to be established in 
Table 1. 16 blocks used for root starch, sap collection, and taphole diameter measurements

\begin{tabular}{llcc}
\hline $\begin{array}{l}\text { Physiographic } \\
\text { Region }\end{array}$ & $\begin{array}{l}\text { Damage } \\
\text { Class }\end{array}$ & $\begin{array}{c}\text { Percent } \\
\text { Damage }\end{array}$ & $\begin{array}{c}\text { Sap Years } \\
\text { Sampled }\end{array}$ \\
\hline Limestone Plain & Severe & 57 & 00 and 01 \\
Canadian Shield & Moderate & 42 & $99,00,01$ \\
Limestone Plain & Light & 7 & $99,00,01$ \\
Limestone Plain & Severe & 63 & $99,00,01$ \\
Canadian shield & Severe & 61 & 99 \\
St. Lawrence Valley & Severe & 71 & $99,00,01$ \\
Canadian Shield & Severe & 69 & $99,00,01$ \\
Limestone Plain & Moderate & 43 & $99,00,01$ \\
Canadian Shield & Light & 12 & $99,00,01$ \\
Canadian Shield & Light & 22 & $99,00,01$ \\
St. Lawrence Valley & Severe & 61 & $99,00,01$ \\
St. Lawrence Valley & Moderate & 41 & $99,00,01$ \\
St. Lawrence Valley & Moderate & 40 & $99,00,01$ \\
Ottawa Valley & Severe & 72 & $99,00,01$ \\
Ottawa Valley & Light & 20 & $99,00,01$ \\
Ottawa Valley & Moderate & 32 & $99,00,01$ \\
\hline
\end{tabular}

each physiographic region for a total of 36 plots. However, because of the pattern of ice storm-induced damage, three replications of each damage level (especially light damage) were not always possible in each region. This study was one of many using the same plot network to investigate the impact of the 1998 ice storm on the sugar bushes of eastern Ontario (Lautenschlager and Nielsen 1999).

Relationships between each response variable (i.e., root starch and sugars, sap volume and sugar content, and calculated syrup production) and the explanatory variables were examined using regression and ANOVA techniques (SAS 1996). Although set up as a completely randomized block design, this portion of the study was analyzed with each individual tree considered an independent sample unit in the statistical analyses. This was done because ice storm damage was applied to individual trees, and even within a block, the range in individual focus tree damage was often as high as $20 \%$ or more (e.g., a $25 \%$ to $45 \%$ focustree damage range for a moderately damaged block). In addition, the response of each tree, in terms of root starch, sap and syrup production, was independent of the other trees in the block. Residuals were plotted and checked for normality and homogeneity of variance. In the case of significant categorical variables, a posteriori means testing was carried out using the Ryan-Einot-Gabriel-Welsch means test $(P \leq 0.05)$ (SAS 1996).

\section{Results}

\section{Root Starch and Total Sugars}

Ice storm damage definitely affected root starch levels in sugar maple trees (Fig. 1). Severely damaged trees had less $(P \leq 0.05)$ starch in their roots in 1998 and 2000 than did light or moderately damaged trees, but the difference was not significant in 1999. Comparisons among years show the average root starch content of all tapped trees was similar in $1998(1.87 \% \pm 0.09)$ and $1999(1.84 \% \pm 0.07)$, but lower levels in $2000(1.43 \% \pm$ $0.05, P \leq 0.05)$.

Other factors such as root diameter, live branch count, dbh, and soil $\mathrm{K}$ were significantly, but weakly (all but one $\mathrm{r}^{2} \leq 0.054$ ), correlated with root starch content, but not consistently in every year (Table 2). Root starch content was positively correlated with root diameter in 1998 and 2000 but not in 1999. A positive correlation was found between dbh and root starch content in 1998 and 1999, but not in 2000. Live branch num-

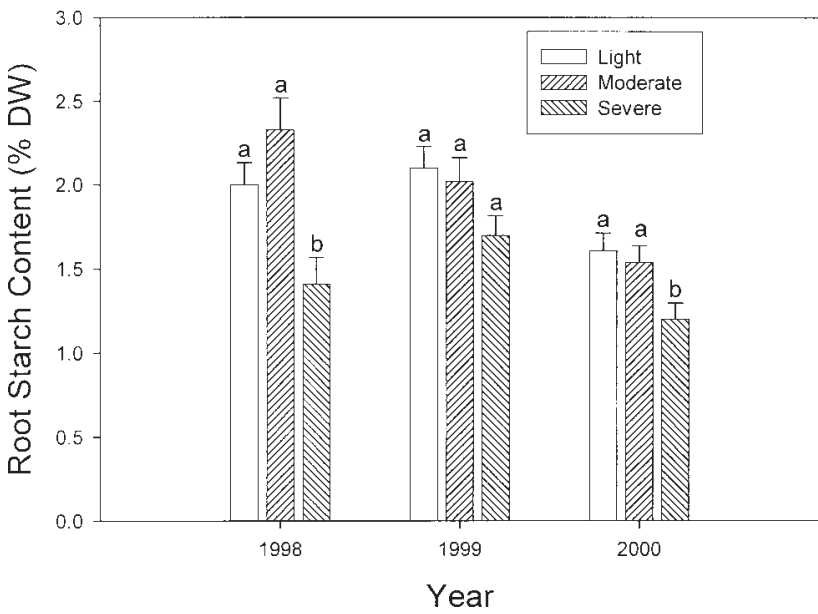

Fig. 1. Effect of ice storm damage on fall root starch levels in sugar maple trees from 15 tapped and 1 non-tapped maple stands in Eastern Ontario (Mean + Std. Error). Any columns within a year topped by different letters are significantly different $(\mathrm{p} \leq 0.05)$.

bers and soil K content were positively correlated with root starch content in 1998 and 1999, respectively, but not in the other years. Fall root starch levels were not correlated with sap production or sweetness in the following spring $\left(\mathrm{r}^{2} \leq 0.01, P \geq 0.10\right)$ (data not shown).

Ice storm damage and other factors also affected the fall root sugar content in 2000 (Table 3). Severely damaged trees had significantly lower root sugar levels than lightly or moderately damaged trees. Root sugar levels also were positively correlated with live branch count $\mathrm{r}^{2}=0.14(P \leq 0.0001)$ and $\mathrm{dbh}$ $\mathrm{r}^{2}=0.08(P \leq 0.0005)$. Soil factors such as soil calcium $\mathrm{r}^{2}=0.09$, magnesium $\mathrm{r}^{2}=0.06$, potassium $\mathrm{r}^{2}=0.03$, and clay content $r^{2}=0.07$ were all significantly $(\mathrm{p} \leq 0.05)$ and positively, but weakly, correlated with root sugar content.

\section{Sap Volume and Sweetness}

Sap volume was negatively affected by ice storm damage but sap volume was not consistently affected from year to year (Fig. 2). In 1999, no significant affects of ice storm damage were apparent when comparing sap production from the light, moderate and severe damage levels. However, if the damage levels are grouped differently, trees with $0-20 \%$ crown damage produced 45.1 litres of sap per tap in 1999 , more $(\mathrm{p} \leq 0.05)$ than the 38.7 litres per tap produced by the trees with greater than $20 \%$ crown loss. Although only moderately damaged trees produced less sap in 2000, in 2001 both moderately and severely damaged trees had significantly lower yields of sap per tap.

The impact of ice storm damage on sap sweetness was variable (Table 4). In 1999, the moderately damaged trees had the sweetest sap, while the moderately and severely damaged trees produced sap with about $15 \%$ less sugar in the 2000 sap run. In 2001, the severely damaged trees produced the sweetest sap.

\section{Syrup Production}

Potential syrup production was reduced $(\mathrm{p} \leq 0.05)$ by ice storm damage (Fig. 3). For example, in 1999 the syrup production of severely damaged trees was calculated to be about $25 \%$ less than in lightly or moderately damaged trees. Compared to lightly damaged trees, moderately and severely damaged trees had a 
Table 2. Pearson coefficient of determination matrix and probabilities of root starch content with root diameter, diameter breast high (dbh), live branch number, and soil potassium (K) content

\begin{tabular}{|c|c|c|c|c|c|c|c|c|}
\hline Year & $\begin{array}{c}\text { Root Dia } \\
\mathbf{r}^{2}\end{array}$ & $\begin{array}{c}\text { Root Dia } \\
\mathbf{P}>\mathbf{F}\end{array}$ & dbh $\mathbf{r}^{2}$ & dbh $P>F$ & $\begin{array}{c}\text { Live } \\
\text { Branch } \mathbf{r}^{2}\end{array}$ & $\begin{array}{c}\text { Live Branch } \\
\quad \mathbf{P}>\mathbf{F}\end{array}$ & Soil $K \mathbf{r}^{2}$ & Soil K P > F \\
\hline 1998 & 0.146 & 0.0001 & 0.023 & 0.0426 & 0.046 & 0.0037 & 0.014 & 0.1043 \\
\hline 1999 & 0.002 & 0.5364 & 0.043 & 0.0052 & 0.011 & 0.1682 & 0.054 & 0.0017 \\
\hline 2000 & 0.034 & 0.0449 & 0.002 & 0.5478 & 0.009 & 0.1893 & 0.009 & 0.1909 \\
\hline
\end{tabular}

Table 3. Effect of ice storm damage on year 2000 fall root sugar levels in sugar maple trees from 15 tapped and one non-tapped maple stands in Eastern Ontario (Mean \pm Std. Error). Any mean in a column followed by the same letter is not significantly different $(p \leq 0.05)$

\begin{tabular}{lcc}
\hline Damage Level & $\begin{array}{c}\text { Root Total Sugars } \\
(\% \mathbf{D W})\end{array}$ & $\begin{array}{c}\text { Root Total } \\
\text { Non-structural } \\
\text { Carbohydrates } \\
(\% \mathbf{D W})\end{array}$ \\
\hline Light & $4.11 \pm 0.09 \mathrm{a}$ & $5.71 \pm 0.16 \mathrm{a}$ \\
Moderate & $4.03 \pm 0.11 \mathrm{a}$ & $5.57 \pm 0.16 \mathrm{a}$ \\
Severe & $3.79 \pm 0.08 \mathrm{~b}$ & $4.98 \pm 0.15 \mathrm{~b}$ \\
\hline
\end{tabular}

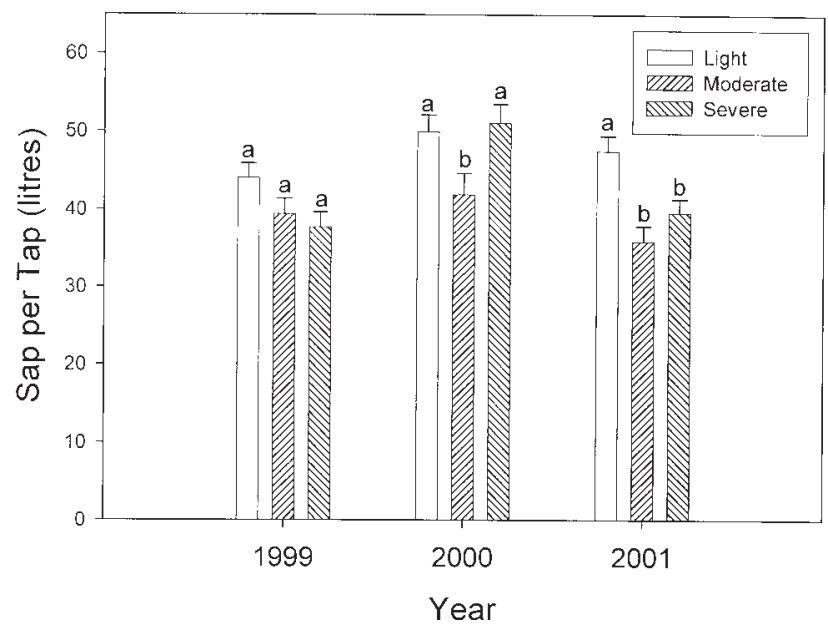

Fig. 2. Ice storm damage impact on seasonal sap volume production in sugar maple trees from 15 tapped stands in Eastern Ontario (Mean + Std. Error). Any columns within a year topped by different letters are significantly different $(\mathrm{p} \leq 0.05)$.

similar reduction in calculated syrup production in 2000. In 2001, the moderately damaged trees had less potential syrup production than lightly or severely damaged trees. Overall mean calculated syrup production per tap for maples of all damage levels was higher ( $\mathrm{p} \leq 0.05)$ in $2000(1.11 \mathrm{l} / \mathrm{tap})$ than in $1999(0.82 \mathrm{l} / \mathrm{tap})$ or 2001 (0.85 l/tap).

\section{Total Branch Count}

The total number of branches per tree was positively correlated with sap production in all three years, but was only correlated with sap sugar and syrup production in 1999 (Table 5). However, if one block (an outlier) that had trees with the highest branch counts and low sap production in 2000 and 2001 is removed from the analysis, the relationship usually becomes significant for both sap sugar content and syrup/tap in both years (data not shown).

\section{Tap hole Closure}

The effect of crown damage on tap hole closure rate varied from year to year with no clear relationship evident (Fig. 4 and Table 6). For example, after one year, tap holes closed faster in severely damaged trees for 1999 tap holes, then faster
Table 4. Ice storm damage impact on seasonal average sap total sugar content in sugar maple trees in Eastern Ontario (Mean \pm Std. Error). Any mean in a column followed by the same letter is not significantly different $(\mathbf{p} \leq \mathbf{0 . 0 5})$

\begin{tabular}{lccc}
\hline Damage Level & $\begin{array}{c}\text { 1999 Sap Sugar } \\
\text { Content }(\%)\end{array}$ & $\begin{array}{c}\text { 2000 Sap Sugar } \\
\text { Content }(\%)\end{array}$ & $\begin{array}{c}\text { 2001 Sap Sugar } \\
\text { Content }(\%)\end{array}$ \\
\hline Light & $1.74 \pm 0.11 \mathrm{ab}$ & $2.25 \pm 0.12 \mathrm{a}$ & $1.73 \pm 0.41 \mathrm{~b}$ \\
Moderate & $2.00 \pm 0.12 \mathrm{a}$ & $1.97 \pm 0.04 \mathrm{~b}$ & $1.73 \pm 0.05 \mathrm{~b}$ \\
Severe & $1.57 \pm 0.12 \mathrm{~b}$ & $1.94 \pm 0.06 \mathrm{~b}$ & $1.93 \pm 0.04 \mathrm{a}$ \\
\hline
\end{tabular}

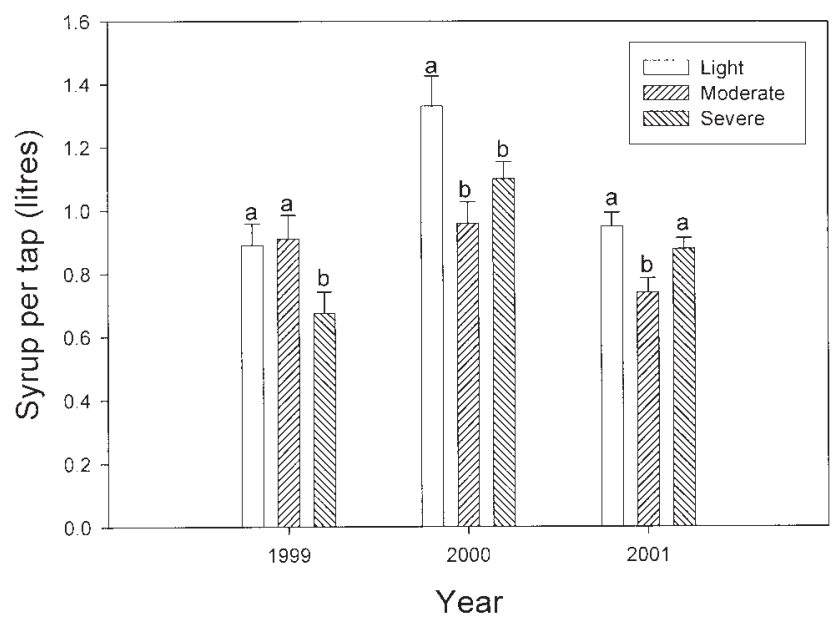

Fig. 3. Ice storm damage impact on calculated syrup production in sugar maple trees from 15 tapped stands in Eastern Ontario (Mean + Std. Error). Any columns within a year topped by different letters are significantly different $(\mathrm{p} \leq 0.05)$.

in moderately damaged trees for 2000 tap holes, while 2001 tap holes showed no rate of closure differences related to damage. Although tap holes for all levels of damage were significantly smaller than the initial diameter after one year, they were still less than $50 \%$ closed after one year. After two to three growing seasons, there were no damage-related significant differences in tap hole closure rate. The only other factors that appeared to be positively correlated with tap hole closure rate were soil $\mathrm{pH}$ and soil Ca levels. Ca was significantly (but weakly) correlated with tap hole closure rate in all measurement except year 11999 tap hole closure rates $(p=0.0521)$. The coefficients of determination for $\mathrm{Ca}$ and tap hole closure ranged from $r^{2}=0.03$ to $r^{2}=0.11$. Although soil $\mathrm{pH}$ also was positively correlated with tap hole closure rate, the relationship was decidedly weaker with $\mathrm{pH}$ only significant in four out of six tap hole closure measurements.

\section{Physiographic Region and Treatments}

Some regional differences were found in 1999 and 2001 sap production and in syrup production in all years, but no consistent regional trends were evident (Data not shown). Dolomitic 
Table 5. Pearson coefficient of determination matrix and probabilities of total branch count correlated to sap/tap, seasonal average sap sugar concentration and syrup/tap for 15 blocks in Eastern Ontario for three years

\begin{tabular}{lcccccc}
\hline Year & Sap/tap $\mathbf{~}^{\mathbf{2}}$ & Prob. $\leq$ & Sap Sugar $\mathbf{r}^{\mathbf{2}}$ & Prob. $\leq$ & Syrup/tap r $^{\mathbf{2}}$ & Prob. $\leq^{\leq}$ \\
\hline 1999 & 0.0682 & 0.0032 & 0.1496 & 0.0001 & 0.2793 & 0.0001 \\
2000 & 0.0689 & 0.0019 & 0.0021 & 0.5395 & 0.0043 & 0.3834 \\
2001 & 0.1141 & 0.0001 & 0.0057 & 0.3155 & 0.0004 & 0.7919 \\
\hline
\end{tabular}

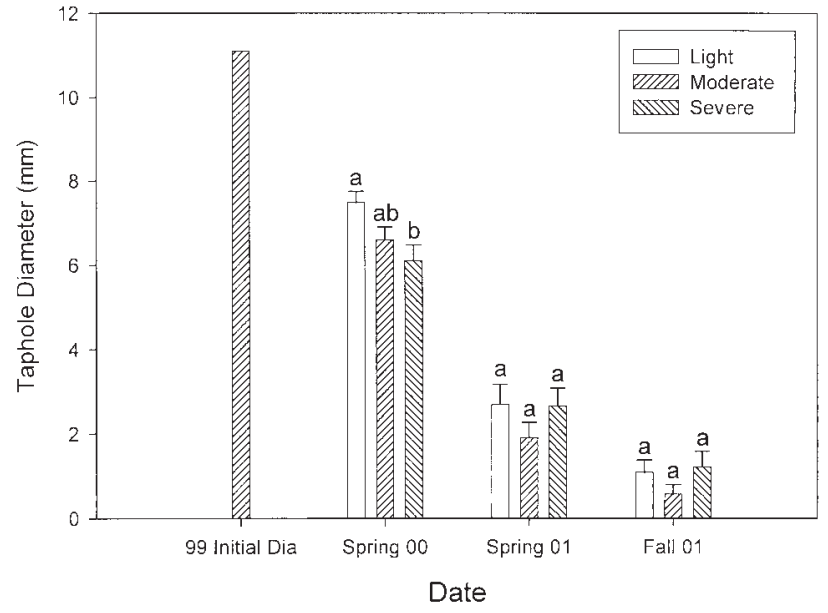

Fig. 4. Initial 1999 taphole diameter and diameter after one, two, and three growing seasons as affected by crown damage in 15 tapped stands in Eastern Ontario (Mean + Std. Error). Any columns within a group topped by different letters are significantly different $(p \leq 0.05)$.

lime and fertilizer treatments did not have a significant affect on any of the measured variables including the amino acid content of sap (Table 7).

\section{Discussion}

The crown of a sugar maple tree is its photosynthetic factory for producing sugar. By removing a significant portion of this crown, the ice storm of 1998 reduced the capacity of the tree to produce energy (sugar) needed for growth and development. Storm damage was assessed as the percentage of live crown removed. Although this provides a rough assessment of the ice storm impact on the tree's ability to produce energy, it does not account for differences in initial crown size between trees and the differing ability with age (Kramer and Kozlowski 1979) and crown classification (Meating et $a l$. 2000) to sprout new epicormic branches to replace lost ones. Therefore, the impact of $50 \%$ damage on one tree that initially had 50 tertiary branches may not have been as great as on a second tree that had 20 such branches before the storm. This led to the effort to quantify the number of live and epicormic branches on the focus trees used for this experiment (Lautenschlager and Winters 2001). In addition, the age of the tree and its condition prior to the storm (Proulx and Greene 2001) also will influence the degree to which it will be affected by ice storm damage. The combination of these factors and weather patterns in the eastern Ontario region during the growing seasons (Parker 2003) after the storm are likely reasons why response to the ice storm was variable from stand to stand; these factors have been considered when interpreting the results.

The severe level of damage ( $>50 \%$ ) reduced fall root starch levels and total sugar content of sugar maple roots. To my knowl-
Table 6. Initial 2000 and 2001 taphole diameter and diameter after one or two as affected by crown damage (Mean \pm Std. Error). Any mean in a column followed by the same letter is not significantly different $(\mathbf{p}<0.05)$

\begin{tabular}{lccc}
\hline Damage Level & $\begin{array}{c}\text { '00 Tap hole } \\
\text { Diameter }(\mathbf{m m}) \\
\text { Spring '01 }\end{array}$ & $\begin{array}{c}\text { '00 Tap hole } \\
\text { Diameter }(\mathbf{m m}) \\
\text { Fall '01 }\end{array}$ & $\begin{array}{c}\text { '01 Tap hole } \\
\text { Diameter }(\mathbf{m m}) \\
\text { Fall '01 }\end{array}$ \\
\hline Initial Diameter & $11.1 \pm 0.0 \mathrm{a}$ & $11.1 \pm 0.0 \mathrm{a}$ & $11.1 \pm 0.0 \mathrm{a}$ \\
Light & $7.29 \pm 0.32 \mathrm{~b}$ & $3.54 \pm 0.43 \mathrm{~b}$ & $7.98 \pm 0.23 \mathrm{~b}$ \\
Moderate & $5.91 \pm 0.28 \mathrm{c}$ & $2.36 \pm 0.36 \mathrm{~b}$ & $7.22 \pm 0.25 \mathrm{~b}$ \\
Severe & $6.84 \pm 0.30 \mathrm{~b}$ & $2.69 \pm 0.34 \mathrm{~b}$ & $7.23 \pm 0.28 \mathrm{~b}$ \\
\hline
\end{tabular}

Table 7. Mean seasonal total amino acid content of sap from Block 14 in the 2000 sap run (Mean \pm Std. Error). Any mean followed by the same letter is not significantly different $(\mathbf{p}<\mathbf{0 . 0 5})$

\begin{tabular}{lc}
\hline Treatment & Sap Total Amino Acid Content $(\mathbf{n M} / \mathbf{m l})$ \\
\hline Control & $1.48 \pm 0.25 \mathrm{a}$ \\
Dolomitic Lime & $1.77 \pm 0.21 \mathrm{a}$ \\
P and K & $1.42 \pm 0.11 \mathrm{a}$ \\
Lime \& P and K & $1.30 \pm 0.11 \mathrm{a}$ \\
\hline
\end{tabular}

edge, this is the first time ice-storm-induced crown damage has been shown to reduce root starch content. Reductions in autumn root starch levels have been reported for sugar maple trees where crown dieback equalled or exceeded 50\% (Renaud and Mauffette 1991). However, they also found that the same trees had elevated levels of fall root sugars (glucose and fructose). Mortality of sugar maple has been associated with shoot and root starch depletion in artificially defoliated trees (Gregory and Wargo 1986). Severe insect defoliation reduced fall root starch levels in sugar maple (Kolb et al. 1992). Other ice storm studies estimated that, for hardwoods, a 40-50\% crown loss was the critical level above which tree death tended to increase rapidly with increased damage (Boulet et al. 2000, Proulx and Greene 2001). The 50\% crown damage threshold for root starch depletion found in this study tends to support this critical crown damage threshold for mortality. However, these studies and others found a wide range of projected or measured mortality with crown loss; in general, mortality was proportional to damage (Proulx and Greene 2001).

Root starch levels of severely damaged trees were not significantly affected by crown damage in 1999. This suggests that variable growing conditions during the different years (Parker 2003) also may affect the fall root starch levels. Other factors correlated with and possibly influencing autumn root starch content appear to be of little or no importance.

Ice storm damage effects on sap production, sap sweetness, and syrup production were usually negative but variable. Sap volume was significantly reduced by crown damage in two of the three years measured. However, damage effects on sap sugar content were more variable and that variability may have been due to inherent natural variability and the effects of other environmental factors. Syrup production was significantly reduced by damage in all three years, but only in moderately damaged trees in 2001. In his review, Coons (1999) could not 
find any previous literature documenting the effect of ice storms on sugar maple sap and syrup production. This, to my knowledge, is the first evidence that ice-storm-induced damage to sugar maple crowns reduces sap sweetness, sap volume, and syrup production. Insect defoliation has been shown to lower sap production and sweetness in Pennsylvania. The higher sap sugar content in the severely damaged trees in 2001 is similar to the finding by Kolb et al. (1992) that the second year after insect defoliation, sap sweetness was highest in the heavily (60-90\% foliage damage) damaged maples.

Total branch count was consistently and positively correlated with sap per tap production in all three years, which suggests that ice-storm removal of branches is one mechanism that reduces sap production. This finding is consistent with evidence on how the colder temperatures at night freeze the sap in the outer branches first causing sap flow up the tree to replace the frozen sap (Tyree 1983, Tyree 1984).

Lime and fertilizer treatments did not have a significant effect on any of the variables measured in this study. Since amino acids are thought to be the compounds that impart the maple taste to maple syrup (Morselli and Whalen 1986 as cited in Koelling and Heiligmann 1996), the lack of an effect of the lime and fertilizer treatments on the total amino acid content of the sap was of particular interest to maple syrup producers. If any of the lime and $\mathrm{P}$ and $\mathrm{K}$ treatments are found to enhance recovery sugar maple from crown damage (Lautenschlager et al. 2003, Timmer et al. 2003) this result suggests that such treatments could be used in the future with no effect on the taste or quality of the syrup. However, sugar maple response to liming treatments is a long-term phenomenon (Long et al. 1997) and it is too early to make any definitive conclusions on liming treatment effects.

The maple tree's ability to heal wounds did not seem to be affected much by the level of crown damage. Other studies have reported that wound healing usually progresses slower in defoliated maples (Wargo 1977), so the lack of an effect of crown damage on tap hole closure rate was somewhat unexpected. It is likely that natural variability in wound healing response obscured any tendency for damage to inhibit the tap wound closure process. It is also possible that tap hole wounds were too small to detect any effects of degree of damage on the wound healing process.

In conclusion, ice-storm-damaged sugar maple crowns tended to have less syrup productive capacity and lower root starch levels, especially in trees with more than $50 \%$ crown damage. The effect of the damage lasted up to three years after the ice storm.

\section{Acknowledgements}

This research project would not have been possible without the assistance of Mr. Geoff McVey, the ice storm field co-ordinator. Mr. Denzil Irving also provided valuable field technical assistance. Mr. Desmond Hickie, Ms. Maara Packalen, and Ms. Leslie Rich provided excellent technical assistance in the laboratory. Mr. John Pedlar provided statistical analyses. The Ice Storm Forest Research and Technology Transfer (ISFRATT) program co-ordinators Ms. Cathy Nielsen and Dr. R. A. Lautenschlager provided administrative support. Funding for this project has been provided under the CanadaOntario Agreement for the Ice Storm Economic Recovery Assistance Program, Annex A, Assistance for the Agricultural Sector and Rural Communities in Eastern Ontario. Miller
Consulting collected sap volume and sweetness samples. Finally, by providing research plots, the maple sugar bush owners of eastern Ontario were critical to the success of this project.

\section{References}

Boulet, B., F. Trottier and G. Roy. 2000. Management of ice storm damaged stands. Min. Res. Nat., Gov. du Quebec. ISBN:2-55035993-3. 65 p.

Chapeskie, D.J. 1999. Ice storm damage to sugar bushes in Ontario. New York Society of American Foresters Ice Storm Symposium, Cortland, New York. pp. 21-24. USDA Forest Service, NE Area State and Private Forestry, Publication: NA-TP-03-01.

Chapeskie, D.J. and C.M. Nielsen. 1998. Interim guidelines for tapping and restoration of sugar maple bushes affected by the ice storm of January 1998. Joint OMAFRA/OMNR Internal Report, Kemptville, ON. 12 p.

Coons, C.F. 1999. Effects of ice storm damage and other stressors on sugar bush health and sap productivity: literature review and synthesis. Ontario Ministry of Natural Resources, Ice Storm Forest Research and Technology Transfer. $75 \mathrm{p}$.

Gregory, R.A. and P.M. Wargo. 1986. Timing of defoliation and its effect on bud development, starch reserves, and sap sugar concentration in maple. Can. J. For. Res. 16: 10-17.

Haissig, B.E. and R.E. Dickson. 1979. Starch measurement in plant tissue using enzymatic hydrolysis. Physiologia Plantarum 47: 151-157. Irland, L.C. 1998. Ice storm 1998 and the forest of the northeast: a preliminary assessment. J. For. 96(9): 32-40.

Koelling, M.R. and R.B. Heiligmann (eds.). 1996. North American Maple Syrup Producers Manual, Bulletin 856. The Ohio State University Extension, Columbus, $\mathrm{OH}$.

Kolb, T.E., L.H. McCormick, E.E. Simons and D.J. Jeffery. 1992. Impacts of pear thrips damage on root carbohydrate, sap and crown characteristics of sugar maples in a Pennsylvania sugarbush. For. Sci. 38(2): 381-392.

Kramer, P.J. and T.T. Kozlowski. 1979. Physiology of Woody Plants. Academic Press. New York, NY. 811 p.

Lautenschlager, R.A., J.H. Pedlar, J.A. Winters and C.M. Nielsen. 2003. Ice storm damage: Effects of competition and fertilization on near-ground vegetation. For. Chron. 79(1): 54-62.

Lautenschlager, R.A. and C. Nielsen. 1999. Ontario's forest science efforts following the 1998 ice storm. For. Chron. 75(4): 633-641.

Lautenschlager, R.A. and J.A. Winters. 2001. Quantifying ice damage by counting branches on damaged sugar maple trees. For. Chron. 77(4): 637-642.

Long, R.P., S. B. Horsley and P.R. Lilja. 1997. Impact of forest liming on growth and crown vigor of sugar maple and associated hardwoods. Can. J. For. Res. 27: 1560-1573.

Meating, J., O. Van Dyke, A. Boyd and K. Wright. 2000. Management of ice storm damaged woodlots and plantations. Ontario Ministry of Natural Resources. SCSS, ISBN: 0-7778-9263-4. 96 p.

Morselli, M.F. and M.L. Whalen. 1986. Amino acids increase in xylem sap of Acer saccharum prior to bud break. Am. J. Bot. 73: 722-723. Milton, J. and A. Bourque. 1999. A climatological account of the January 1998 ice storm in Quebec. Atmospheric Sciences and Environmental Issues Division, Environment Canada, Quebec Region. 87 p. Noland, T.L., G.H. Mohammed and M. Scott. 1997. The dependence of root growth potential on light level, photosynthetic rate, and root starch content in jack pine seedlings. New Forests 13: 105-119. Parker, W.C. 2003. The effect of ice damage and post-damage fertilization and competition control on understory microclimate of sugar maple (Acer saccharum Marsh.) stands. For. Chron. 79(1): 82-90. Proulx, O.J. and D.F. Greene. 2001. The relationship between ice thickness and northern hardwood tree damage during ice storms. Can. J. For. Res. 31(10): 1758-1767.

Renaud, J.P. and Y. Mauffette. 1991. The relationships of crown dieback with carbohydrate content and growth of sugar maple (Acer saccharum). Can. J. For. Res. 21: 1111-1118. 
SAS. 1996. SAS user's guide: statistics. Release 6.12. SAS Inst. Inc., Cary, N.C. 352 p.

Timmer, V. R., Y. Teng and J. Pedlar. 2003. Soil and leaf analysis of fertilized sugar maple stands after ice storm damage. For. Chron. 79(1): 99-105.

Tyree, M.T. 1983. Maple sap uptake, exudation, and pressure changes correlated with freezing exotherms and thawing endotherms. Plant Physiol. 73: 277-285.

Tyree, M.T. 1984. Maple sap exudation: how it happens. Maple Syrup Journal 4(1): 10-11.

Van Dyke, O. 1999. A literature review of ice storm impact on forests in Eastern North America. Ministry of Natural Resources, SCSS, North Bay, ON. ISBN: 0-7778-8477-1. 29 p.
Walters, R.S. 1982. Sugarbush management. In Sugar Maple Research: Sap Production, Processing, and Marketing of Maple Syrup. pp. 25-37. USDA For. Ser., NE For. Exp. Sta., Gen. Tech. Rep. NE-72.

Wargo, P. 1977. Wound closure in sugar maple: adverse effects of defoliation. Can. J. For. Res. 7: 410-414.

Wargo, P. 1979. Starch storage and radial growth in woody roots of sugar maple. Can. J. For. Res. 9: 49-56.

Wargo, P.M., J. Parker and D.R. Houston. 1972. Starch content in roots of defoliated sugar maple. For. Sci. 18: 203-204. 